\title{
Pengaruh Biaya, Angsuran dan Kualitas Pelayanan Terhadap Kepuasan Nasabah Pembiayaan BMT di Kabupaten Kudus
}

\author{
Wahibur Rokhman \\ Prodi Ekonomi Syari'ah, STAIN Kudus \\ Wahibur@gmail.com
}

\begin{abstract}
Abstrak
Penelitian ini bertujuan untuk menguji pengaruh biaya pinjaman (cost of loan), angsuran pinjaman (loan repayment), dan kualitas pelayanan terhadap kepuasan nasabah pembiayaan Baitul mal wat tamwil (BMT) di kabupaten Kudus.Sampel dalam penelitian ini adalah konsumen pembiayaan BMT yang telah menjadi nasabah di atas 1 tahun dengan menggunakan tehnik purposive sampling. 150 kuesioner didistribusikan ke nasabah pembiayaan di 10 BMT yang beroperasi di Kabupaten Kudus. Kuesioner yang kembali sebanyak 112 kuesioner tetapi hanya 96 kuesioner yang dapat dianalisis lanjutan. Hasil penelitian ini menunjukkan bahwa angsuran dan kualitas pelayanan pengaruh yang positif signifikan terhadap kepuasan nasabah pembiayaan. Sedangkan biaya pinjaman tidak berpengaruh terhadap kepuasan nasabah pembiayaan. Implikasi, keterbatasan dan saran untuk penelitian yang akan datang juga dibahas dalam artikel ini.
\end{abstract}

Kata Kunci: Biaya pinjaman, angsuran pinjaman, kualitas pelayanan dan Kepuasan Konsumen pembiayaan.

\section{Abstract}

The aim of this research was to examine the influence of cost of credit, loan repayment, and service quality on microcredit's customer satisfaction of Baitul mal wat tamwil (BMT) in Kudus Regency. This study used a sample of microcredit customers which more than 1 year became customer. This study used purposive sampling method. 150 questioners distributed to 
microcredit's customer in 10 BMTs in Kudus. 112 questioners are returned; only 96 fulfill the requirements. The empirical tests indicated that loan repayment and service quality have significant effect on microcredit's customer satisfaction. However, cost of credit has no significant effect on microcredit's customer satisfaction. Implication, limitation and suggestion for future research are discussed.

Keywords: cost of credit, loan repayment, service quality and microcredit's customer satisfaction

\section{PENDAHULUAN}

Krisis ekonomi memiliki dampak yang sangat signifikan terhadap perkembangan usaha mikro, kecil dan menengah (UMKM) di Indonesia. Pemutusan hubungan kerja (PHK) yang terjadi di hampir seluruh sektor usaha baik industri manufaktur, asuransi, perbankan, dan lainnya yang mengakibatkan pengangguran besar-besaran di Indonesia. Kondisi ini diperparah dengan jatuhnya nilai tukar rupiah di pasar internasional. Tingginya nilai dolar Amerika ini berdampak besar terhadap kehidupan masyarakat, hal ini disebabkan karena mayoritas produk yang beredar di masyarakat merupakan produk impor maupun berbahan baku impor. Sehingga harga produk-produk impor atau yang berbahan baku impor tidak terjangkau oleh kemampuan masyarakat (Soesastro dan Basri, 2005).

Kesempatan kerja yang terbatas dan penurunan daya beli masyarakat akibat krisis, menjadi peluang yang dimanfaatkan masyarakat untuk memulai usaha atau berwirausaha. Masyarakat menciptakan produk subtitusi untuk memenuhi permintaan produk impor yang harganya melambung diluar kemampuan konsumen, sehingga usaha kecil mulai tumbuh di Indonesia. Perkembangan UMKM juga mendorong penyerapan tenaga kerja yang cukup besar, hal ini berdampak pada pengurangan pengangguran di masyarakat. Berdasarkan data kementrian koperasi menunjukkan bahwa kontribusi sektor UMKM terhadap produk domestik bruto sebesar 60,34 persen 
dengan tingkat serapan tenaga kerja sebesar 97 persen (BI, 2016).

Namun demikian, kontribusi UMKM Indonesia terhadap pasokan produk global hanya sebesar 2.7 persen, hal ini menunjukkan bahwa kondisi UMKM Indonesia jauh tertinggal bila dengan UMKM yang ada di negara-negara ASEAN (BI, 2016). Kecilnya kontribusi UMKM di Indonesia dibanding negara lain disebabkan berbagai persoalan yang membelit Usaha kecil, seperti: permodalan, pemasaran, produksi, sumberdaya manusia dan lainnya. Berbagai tantangan yang dihadapi oleh usaha kecil perlu dipecahkan dan dicarikan solusi agar usaha kecil mampu memanfaatkan peluang yang ada. Peran pemerintah dan masyarakat sangat penting untuk mendukung usaha kecil untuk mencapai keunggulan bersaing sehingga mampu bersaing dengan UMKM negara lain.

Pembiayaan menjadi kendala utama yang dihadapi oleh UMKM di negeri ini dalam mencapai keunggulan bersaing baik ditingkat lokal maupun global. Sedangkan di berbagai negara problem ini telah diselesaikan dengan baik dengan berbagai alternatif pembiayaan non bank, sedangkan di Indonesia perbankan masih menjadi sumber utama permodalan bagi usaha kecil (BI, 2016). Di beberapa negara, sumber pembiayaan usaha kecil cukup tersedia tanpa membutuhkan jaminan. Sumber dana itu berasal dariEquity financing seperti angel investors, modal ventura, atau private equity. Sumber pembiayaan tersebut tidak hanya ada di negara maju tetapi juga ada di negara berkembang seperti di Tanzania memiliki Tanzania Venture Capital, di Thailand memiliki SME Investment and Restructuring Fund (SIRF), Laos memiliki Mekong SME Fund (MSMEF) dan banyak negara lain yang bertujuan membiayai dan mendanai UMKM tanpa ada nya jaminan, dananya berasal dari berbagai sumber baik dari venture swasta, corporate sosial responsibility dari berbagai perusahaan, pemerintah dan sumber-sumber lainnya (BI, 2016).

Untuk mengatasi persoalan permodalan UMKM di Indonesia, lembaga keuangan mikro syariah (LKMS)dalam hal ini koperasi jasa keuangan syariah atau Baitul Maal Wat Tamwil (BMT) untuk mengambil peran penting dalam pemberdayaan usaha kecil (Wardiwiyono, 2012). Ada beberapa alasan mengapa lembaga keuangan mikro syariah memiliki peran 
penting dalam perberdayaan usaha kecil: pertama, keberadaan lembaga keuangan mikro syariah yang dekat dengan usaha kecil. Keberadaan BMT di lingkungan masyarakat terutama di daerah pinggiran, di tengah pasar atau di daerah pedesaan menjadikan akses usaha kecil lebih mudah karena tidak perlu ke kota dimana perbankan berada. Kedua, BMT yang berada di pedesaan atau pinggiran biasanya memiliki karyawan yang berasal dari daerah sekitar, hal ini memudahkan BMTdalam memberikan pinjaman atau pembiayaan karena kepada usaha kecil yang merupakan tetangga atau masyarakat dimana karyawan tinggal, sehingga memudahkan dalam menentukan kelayakan mana pengusaha kecil yang baik dan jujur dan mana yang tidak. Hal ini juga terkait dengan kecepatan dalam pencairan dana pinjaman. Ketiga, keterbatasan permodalan di BMT sesuai dengan kebutuhan permodalan di usaha kecil, sehingga kebutuhan untuk pengembangan usaha kecil bisa dipenuhi dengan pinjaman yang ada di BMT (Widiyanto dan Ismail, 2007; Wardiwiyono, 2012).

Namun demikian BMT menghadapi biaya operasional yang cukup tinggi sehingga berdampak pada tingginya biaya pinjaman, hal ini disebabkan karena beberapa sebab karena jumlah nasabah pinjaman yang banyak dengan jumlah pinjaman yang kecil-kecil sehingga sumberdaya manusia yang dibutuhkan cukup banyak. Jumlah karyawan yang banyak untuk melayani jumlah nasabah yang banyak akan berdampak pada biaya tinggi karena harus membayar karyawan. Dengan biaya operasional yang tinggi akan mempengaruhi besaran biaya yang dibebankan kepada usaha kecil.

Berbagai penelitian menunjukkan bahwa pinjaman mikro memiliki dampak terhadap pengembangan usaha kecil, meningkatkan pendapatan, peningkatan standar hidup, pemberdayaan perempuan, (Gebru dan Paul, 2011; Shirazi dan Khan, 2009; Kessy dan Urion, 2006; Durrani, Usman, Malik, dan Ahmad, 2011). Seperti penelitian Durrani dkk (2011) menemukan adanya pengaruh yang positif antara pinjaman mikro terhadap kesejahteraan dan kemampuan membiayai pendidikan keluarga. Penelitian Rokhman (2013) menemukan adanya pengaruh antara pinjaman mikro terhadap kemajuan usaha, kesejateraan keluarga dan pendidikan keluarga. Ashraf dan Noor (2010) meneliti persepsi nasabah kredit terhadap efektifitas lembaga keuangan mikro. Hasilnya menemukan 
adanya keterkaitan antara persyaratan anggota, biaya pinjaman, tingkat pendapatan, dan ketaatan beragama terhadap kepuasan nasabah pembiayaan mikro di Bangladesh.

Berbagai penelitian sebelumnya telah menguji dampak dari pinjaman mikro dan peran lembaga keuangan dalam memberdayakan usaha kecil dan pengentasan kemiskinan, belumbanyak penelitian yang menguji bagaimana hubungan antara biaya pinjaman, model angsuran dan kualitas pelayanan pada kepuasan nasabah pembiayaan. Oleh karena itu, penelitian ini bertujuan ingin menguji: pertama, bagaimana pengaruh biaya pinjaman terhadap kepuasan nasabah pembiayaan. Kedua, bagaimana pengaruh model angsuran terhadap kepuasan nasabah pembiayaan. Ketiga, penelitian ini ingin menguji bagaimana pengaruh kualitas pelayanan terhadap kepuasan nasabah. Penelitian ini menggunakan nasabah pembiayaan BMT yang ada di kabupaten Kudus.

\section{KAJIAN LITERATUR}

\section{Biaya Pinjaman}

BMT merupakan usaha yang memiliki dua misi yaitu: misi sosial dan misi bisnis. Misi sosial merupakan fungsi baitul maal dari BMT dengan menghimpun dana: zakat, wakaf, infak dan shodaqoh untuk didistribusikan kepada masyarakat yang membutuhkan. Pemanfaatan dana ini bisa dalam bentuk dana produktif maupun dana konsumtif. Penggunaan untuk produktif dengan membiayai pendirian atau pengembangan usaha kecil sehingga menciptakan entrepreneur-entrepreneur baru berasal dari masyarakat yang tidak memiliki modal maupun agunan untuk dijadikan jaminan bank. Pemberdayaan melalui baitul maal ini akan mendorong calon calon pengusaha untuk merintis usaha atau mengembangkan yang sudah ada dengan tanpa membebani dengan bagi hasil atau bunga yang harus ditanggung. Setelah usaha yang dirintis berjalan dengan baik dan mampu membayar pinjaman maka dana ini digulirkan kepada pengusaha lainnya yang membutuhkan pembiayaan (Azis, 2004).

Sedangkan fungsi kedua dari BMT adalah baitul tamwil yang mengemban tujuan bisnis untuk mendapatkan keuntungan. 
Fungsi ini sebagai lembaga intermediasi antara yang kelebihan dana dan fihak yang membutuhkan dana. Fungsi ini hampir mirip dengan usaha yang dijalankan perbankan yang menghimpaun dana dari masyarakat dan menyalurkannya kepada sektor riil dan bisnis yang halal dan menguntungkan. Fungsi ini menjadi fungsi yang dominan yang dilakukan BMT sekarang ini, meskipun demikian, BMT dianggap telah membantu mengatasi kemisninan dengan memberi pinjaman dalam jumlah yang kecil dan jumlah yang cukup banyak (Rokhman, 2013) karena mayoritas nasabah pembiayaan BMT di Indonesia merupakan pedagang kecil sebesar 63,7 persen, sedangkan di Jawa Tengah mayoritas sebesar 73,5 persen, sisanya pegawai dan petani (Sakti, 2013).

Namun demikian, para ahli dan praktisi berselisih pendapat tentang pinjaman mikro ini karena beberapa alasan: pertama, keterbatasan jaminan pinjaman sehingga mendorong kemungkinan besar pinjaman tersebut tidak akan pernah kembali. Kedua, tingginya biaya transaksi, karena jumlah yang dipinjam kecil dengan jumlah usaha kecil yang banyak, hal ini berdampak pada tingginya biaya operasional yang harus ditanggung oleh LKMS. Disamping itu, biaya monitoring yang harus ditanggung oleh LKMS cukup tinggi karena banyaknya jumlah usaha kecil yang harus dimonitor supaya usaha bisa berjalan dengan baik sehingga pengembalian pinjaman dapat dilakukan dengan lancar. Ketiga, pendapatan usaha kecil yang tidak stabil menjadikan usaha kecil tidak bankable, sehingga LKMS lebih cocok karena pembayaran dan setoran yang lebih fleksibel disesuaikan dengan kemampuan usaha kecil untuk membayar. Keempat, kebanyakan pengusaha kecil memiliki tingkat pendidikan yang rendah, hal ini berpengaruh terhadap kemampuan membuat laporan keuangan sehingga tidak memenuhi kualifikasi untuk pinjaman bank (Sakai dan Marijan, 2008).

Penelitian Sakti (2013) menemukan bahwa rata-rata BMT di Jawa memberi tingkat bagi hasil untuk pendanaan sebesar 0,78 dan tingkat margin pembiayaan sebesar 2,37 persen. Sedangkan di Jawa Tengah tingkat margin pembiayaan lebih murah sebesar 1,95 persen.Sedangkan alasan mengambil pembiayaan di BMT karena prosedur yang mudah 52,77 persen, kesesuaian dengan syariah 18,73 persen, tingkat biaya yang 
menarik 16,09 persen, mudah di jangkau 9,50 persen dan aman 2.9 persen (Sakti,2013).

\section{Model Angsuran}

Salah satu keunggulan BMT adalah fleksibilitas dalam menampung dana dan menyalurkan dana melalui pembiayaan. Hal ini disebabkan karena kedekatan hubungan antara nasabah dan BMT, kedekatan ini disebabkan karena karyawan BMT yang terjun langsung ke lapangan menjemput calon nasabah baik penabung maupun nasabah pembiayaan. Disamping itu, mayoritas kantor-kantor BMT berada di sekitar pasar-pasar tradisional, sehingga memudahkan para pedagang pasar untuk menabung atau mengajukan pembiayaan (Sakti, 2013).

Dalam pengelolaan pembiayaan, BMT diuntungkan dengan pelayanan jemput bola karena pengajuan pembiayaan dapat dilakukan dengan cara yang cepat dan mudah oleh pedagang. Karyawan BMT yang setiap hari berinteraksi langsung dengan pedagang pasar akan sangat mudah menentukan apakah seorang pedagang layak diberi pembiayaan atau tidak berdasarkan analisis pengamatan lapangan yang selalu dilakukan. Proses ini cukup efektif dalam menyalurkan pembiayaan karena disalurkan kepada nasabah yang dianggap amanah dan bertanggung jawab. Hal ini berdampak positif bagi BMT karena memiliki nasabah pembiayaan yang baik, dengan angsuran yang lancar.

Model pelayanan jemput bola ini juga dilakukan dalam pembayaran angsuran dari para nasabah pembiayaan.Karena mayoritas pembiayaan di BMT jumlahnya sedikit dan jangka pendek maka biasanya angsuran dilakukan dengan model harian atau mingguan, meskipun ada yang bulanan atau musiman tetapi jumlahnya sangat sedikit. Pembayaran angsuran pembiayaan mikro yang cukup fleksibel menjadikan BMT dan koperasi syariah sangat cocok dengan kebutuhan para pengusaha kecil. Pendapatan yang tidak pasti dan bisa fluktuatif, menjadikan pengusaha kecil tidak mampu membayar angsuran dengan model yang sangat ketat. Angsuran yang sangat fleksibel ini menjadikan pengusaha kecil lebih tenang dalam menjalankan usahanya, karena jika pendapatan pada waktu itu tidak cukup membayar angsuran maka bisa dilakukan dalam waktu yang lain. Model angsuran yang sesuai dengan kemampuan usaha 
kecil ini menjadikan konsumen lebih senang dan puas dengan pelayanan yang diberikan koperasi jasa syariah maupun BMT (Wardiwiyono, 2012).

\section{Kualitas Layanan}

Dalam kondisi persaingan lembaga pembiayaan yang sangat ketat, berbagai lembaga keuangan baik konvensional maupun syariah muncul dan bersaing untuk memenuhi keinginan dan kebutuhan pembiayaan. Maka BMT harus selalu berusaha untuk meningkatkan kepuasan nasabahnya dengan memberikan pelayanan yang berkualitas. Kepuasan nasabah akan menjadi senjata utama BMT dalam menghadapi persaingan, karena nasabah yang puas akan dapat menarik calon nasabah yang lain untuk menjadi konsumen BMT. Kemampuan dalam memenangkan persaingan ini akan menentukan kemampuan lembaga keuangan mikro untuk penguasaan pasar. Kualitas layanan merupakan suatu tindakan yang ditujukan untuk memenuhi kebutuhan dan keinginan konsumen atau nasabah yang dilayani. Baik dan buruknya pelayanan tergantung kemampuan BMT dalam memberi pelayanan yang baik sesuai dengan harapan konsumen pembiayaan.

Menurut Ciptono (2000) untuk memberi kualitas pelayanan yang baik, ada beberapa unsur penting, yaitu: Pertama, kecepatan pelayanan. Pelayanan yang cepat dan responsive terhadap keinginan konsumen akan berdampak pada kualitas pelayanan kepada nasabah. Kedua, Ketepatan. Ketepatan ini terkait dengan respon yang sesuai dengan kebutuhan konsumen, disamping ketepatan waktu pelayanannya. Ketiga, keramahan, keramahan terkait dengan sikap karyawan dalam menghadapi nasabah. Karyawan yang sopan, ramah, dan rapi akan berdampak pada kepuasan nasabah terhadap layanan yang diberikan. Keempat, kenyamanan. Kenyamanan terkait dengan tempat dan fasilitas yang diberikan kepada konsumen.

Kepuasan nasabah BMT merupakan tujuan utama dari pelayanan yang diberikan. Nasabah BMT yang sebagian besar bergerak di bidang usaha mikro dan usaha kecil, mulai dari pedagang sayur, penarik becak, pedagang asongan, pedagang kelontongan, penjahit rumahan, pengrajin kecil, tukang batu, petani, peternak, sampai dengan usaha yang relatif moderen perlu mendapatkan pelayanan yang baik. Pelayanan yang 
diberikan BMT dengan model jemput bola baik bagi penabung maupun pelayanan angsuran menjadi sesuatu yang penting. Di samping itu, keberadaan kantor BMT yang biasanya di tengahtengah atau dekat pasar merupakan bagian pelayanan yang di berikan BMT supaya dekat dengan konsumen serta memudahkan konsumen untuk bertransaksi.

\section{Kepuasan Nasabah Pembiayaan}

Persoalan permodalan menjadi persoalan yang menghambat usaha kecil untuk melakukan ekspansi usaha maupun meningkatkan kapasitas produksi. Ada berbagai program bantuan yang diberikan oleh pemerintah maupun swasta tetapi jumlahnya masih terbatas bila dibandingkan dengan kebutuhan modal usaha kecil (BI, 2016). Sedangkan untuk mendapatkan pinjaman dari perbankan bukan merupakan hal yang mudah bagi pengusaha kecil, ini dikarenakan berbagai persaratan yang harus dipenuhi untuk mendapatkan pinjaman sangat banyak dan komplek. Lebih dari itu, keterbatasan akses informasi menjadikan pengusaha kecil enggan untuk berhubungan dengan bank karena berbagai informasi yang negatif tentang pinjaman bank. Keterbatasan permodalan ini mengahambat usaha kecil untuk berkembang dan memperluas akses pasar dengan menambah kapasitas produksi.

Berbagai penelitian menunjukkan bahwa kredit mikro memiliki peranan penting dalam pengentasan kemiskinan, pemberdayaan usaha kecil, membantu pendidikan keluarga, meningkatkan kemampuan keluarga, membantu pengembangan usaha dan lainnya (Kessy dan Urion, 2006; Shirazi dan Khan, 2009; Gebru dan Paul, 2011; Durrani, Usman, Malik, dan Ahmad, 2011; Rokhman, 2013). Kredit mikro atau pembiayaan mikro merupakan pinjaman dalam jumlah yang kecil untuk membantu usaha kecil yang memiliki beberapa karakteristik yaitu: jumlah pinjaman yang kecil, jangka waku pinjaman yang pendek, tidak memiliki jaminan, angsuran yang fleksibel, dan proses yang cepat (Sakti, 2013).

BMT merupakan lembaga keuangan mikro yang berfungsi sebagai lembaga intermediasi dengan mengumpulkan dana masyarakat yang kelebihan untuk disalurkan kepada masyarakat yang membutuhkan dana. Perhimpunan dana dilakukan melalui tabungan yang dilakukan dengan model jemput bola, yaitu 
mengambil langsung ke tempat usaha nasabah secara regular baik harian, mingguan, maupun tahunan. Disamping tabungan, BMT juga memberi fasilitas pengumpulan dana zakat, infak, shodaqoh dan wakaf untuk disalurkan kepada mustahiq (orang yang berhak menerima) baik untuk usaha konsumtif maupun usaha produktif (Widiyanto, 2007; Sebel dan Agung, 2008).

Ada berbagai produk pembiayaan dalam BMT yaitu: pertama, pembiayaan musyarakah ditujukan untuk mengembangkan usaha dengan menambah modal kerja. Pembiayaan ini digunakan untuk menambah modal diharapkan mampu meningkatkan pendapatan sehingga antara BMT dan pengusaha berbagi keuntungan dengan sistem bagi hasil yang disepakati dalam akad. Kedua, pembiayaan murabahah merupakan jenis pembiayaan untuk membantu membeli barangbarang kebutuhan. BMT mengenakan sistem mark-up/margin terhadap nasabah. Ketiga, pembiayaan ijarah merupakan pembiayaan untuk sewa menyewa dengan pembayaran sesuai perjanjian (Azis, 2004).

Penelitian Sakti (2013) menemukan bahwa pembiayaan BMT secara nasional didominasi oleh akad murabaha sebesar 68.5 persen dari total pembiayaan. Sedangkan di Jawa Tengah portfolio pembiayaan murabaha (jual beli) sebesar 50 persen , mudharabah sebesar 41.32 persen dan musyarakah 8.18 persen. Lebih lanjut, Bashir, Machali dan Mwinyi (2012) menguji pengaruh kualitas pelayanan lembaga keuangan mikro dan peran pemerintah terhadap kepuasan konsumen kredit di Kenya, hasilnya menunjukkan kualitas pelayanan berpengaruh terhadap kepuasan konsumen kredit. 


\section{Hipotesis}

Penelitian ini ingin menguji bagaimana pengaruh biaya, angsuran dan kualitas pelayanan terhadap kepuasan nasabah pembiayaan, adapun model penelitian ini adalah sebagai berikut:

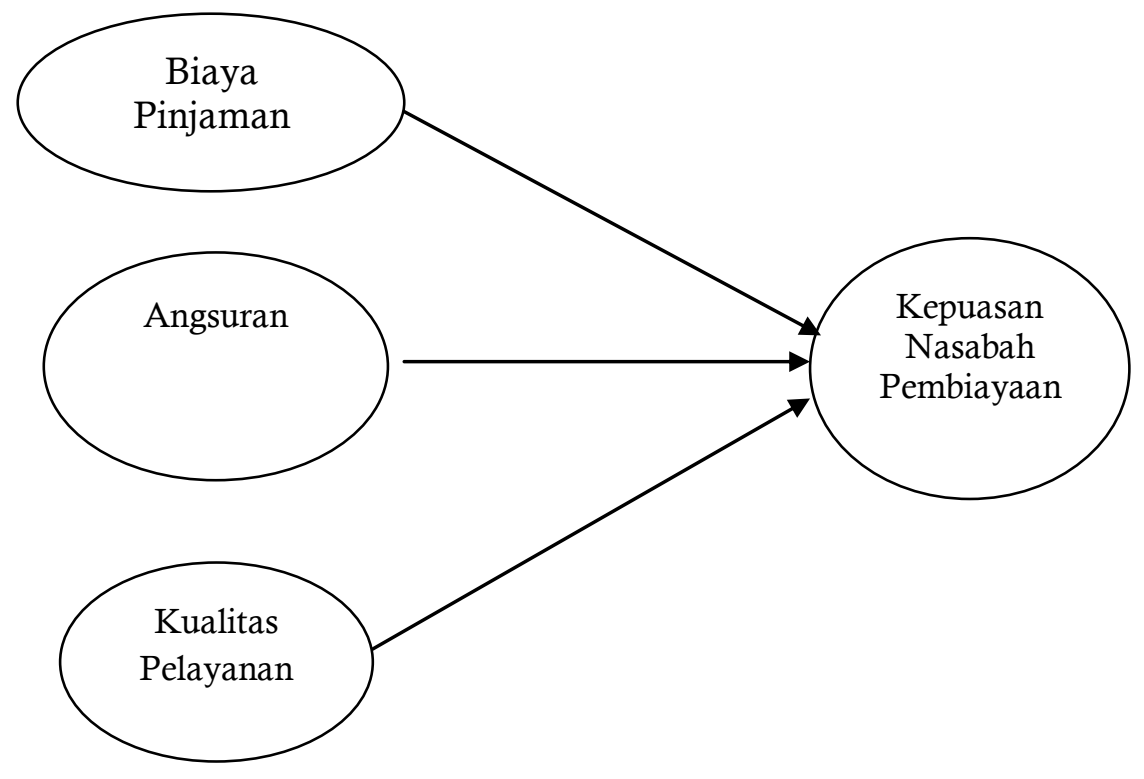

\section{Gambar: Model Penelitian}

Berbagai penelitian menunjukkan bahwa kepuasan konsumen merupakan kunci kesuksesan organisasi dan berpengaruh terhadap loyalitas nasabah (Rokhman dan Harif, 2014). Haris (1997) menemukan lima hal yang harus dipenuhi agar konsumen puas dengan produk atau jasa yaitu: pelayanan, harga, kualitas, tindakan serta penghargaan. Berbagai kegiatan yang di lakukan organisasi pada akhirnya bertujuan untuk memberikan nilai atau value yang bermanfaat buat pelanggan.Perasaan senang dan kecewa seseorang terhadap suatu produk atau jasa dari hasil membandingkan antara yang dipersepsikan terhadap yang diharapkan. Jika yang dipersikan atau dirasakan melebihi ekpektasi maka pelanggan akan puas, jika sebaliknya maka pelanggan tidak puas (Kotler, 2009).

Yusuf, Amao, dan Olawale (2014) meneliti pengaruh kredit mikro terhadap usaha kecil di Negeria. Hasilnya 
menunjukkan bahwa angsuran pinjaman, jumlah keluarga, lama usaha menjadi penentu kemajuan bisnis. Khan, Naeem, dan Kasim (2012) meneliti dampak lembaga keuangan mikro terhadap pengembangan usaha kecil di Baluchistan, Pakistan. Hasilnya menunjukkan bahwa pinjaman mikro merdampak pada peningkatan pendapatan nasabah, kemajuan usaha serta mobiltas sosial dan jaringan meningkat.

Kanyurhi (2013) meneliti kepuasan konsumen terhadap lembaga keuangan mikro. Hasilnya menunjukkan bahwa kantor cabang, pendapatan konsumen dan jumlah layanan berpengaruh terhadap kepuasan konsumen. Sedangkan Masyita dan Ahmed (2011) meneliti tentang faktor faktor yang mempengaruhi permintaan terhadap pembiayaan mikro di BMT dan BPRS dengan sampel 581 nasabah pembiayaan. Hasilnya menunjukkan bahwa alasan utama nasabah mengajukan pembiayaan di lembaga keuangan mikro syariah karena alasan ekonomis dan non ekonomi. Alasan ekonomi karena biaya pinjaman yang rendah dan jumlah pinjaman, sedangkan alasan non ekonomi mengajukan pinjaman seperti: kualitas layanan, kemudahan bertransaksi, kecepatan bertransaksi, kedekatan kantor, cara melayani serta karyawan yang melayani.

Ashraf dan Noor (2010) meneliti persepsi nasabah pembiayaan terhadap lembaga keuangan mikro di Bangladesh. Ada beberapa faktor yang penting yang mempengaruhi kepuasan konsumen yaitu: persyaratan anggota, biaya pinjaman, tingkat pendapatan, larangan agama. Lebih lanjut, Bashir, Machali dan Mwinyi (2012) menguji pengaruh kualitas pelayanan dan peran pemerintah terhadap kepuasan konsumen di Kenya. Penelitian ini menemukan bahwa kualitas pelayanan berpengaruh terhadap kepuasan konsumen, sedangkan peran pemerintah tidak berpengaruh secara signifikan terhadap kepuasan konsumen.

Berdasarkan berbagai penelitian di atas, maka penelitian ini menguji tiga hipotesis sebagai berikut:

H1. Biaya berpengaruh positif signifikan terhadap kepuasan nasabah pembiayaan

$\mathrm{H} 2$. Angsuran berpengaruh positif signifikan terhadap kepuasan nasabah pembiayaan.

H3. Kualitas pelayanan berpengaruh positif signifikan terhadap kepuasan nasabah pembiayaan 


\section{METODE PENELITIAN}

\section{Sampel}

Sampel dalam penelitian ini adalah nasabah pembiayaan dari BMT di kabupaten Kudus. Penelitian ini menggunakan tehnik purposive sampling. Tehnik ini digunakan dengan cara menentukan kreteria tertentu yang digunakan untuk menentukan kelayakan anggota populasi menjadi sampel penelitian. Dalam penelitian ini ada beberapa kreteria untuk menjadi sampel: pertama, nasabah yang memiliki pinjaman di BMT. Kedua, sudah menjadi nasabah pembiayaaan minimal selama 1 tahun di BMT, supaya dapat merasakan bagaimana menjadi konsumen pembiayaan di BMT.

Responden dalam penelitian ini adalah nasabah BMT yang memiliki pinjaman pada BMT di Kabupaten Kudus. Kuesioner yang disebarkan sebanyak 150 buah, namun yang kembali sebanyak 112 buah dengan response rate sebesar $74 \%$. Namun dari kuesiner yang dikembalikan sebanyak 16 buah yang tidak dapat dipakai dalam analisis lanjutan karena banyaknya item yang tidak terisi, sehingga tidak diikutkan dalam analisis penelitian ini. Sehingga total jawaban responden yang bisa dipakai sebanyak 96 buah. Berikut ini gambaran secara umum tentang responden terkait dengan jenis kelamin, pendidikan, usia maupun pengalaman kerja:

Tabel 1. Karakterisik Responden

\begin{tabular}{|l|c|c|}
\hline \multicolumn{1}{|c|}{ Keterangan } & Frequency & Percentage \\
\hline Jenis Kelamin & 47 & \\
Laki-Laki & 49 & $49 \%$ \\
Perempuan & $\mathbf{9 6}$ & $51 \%$ \\
Total & & $\mathbf{1 0 0} \%$ \\
\hline Umur & 34 & $35 \%$ \\
$\geq 25$ & 19 & $20 \%$ \\
$26-30$ & 10 & $10 \%$ \\
$31-35$ & 16 & $17 \%$ \\
$36-40$ & 17 & $18 \%$ \\
$41 \leq$ & $\mathbf{9 6}$ & $\mathbf{1 0 0} \%$ \\
Total &
\end{tabular}




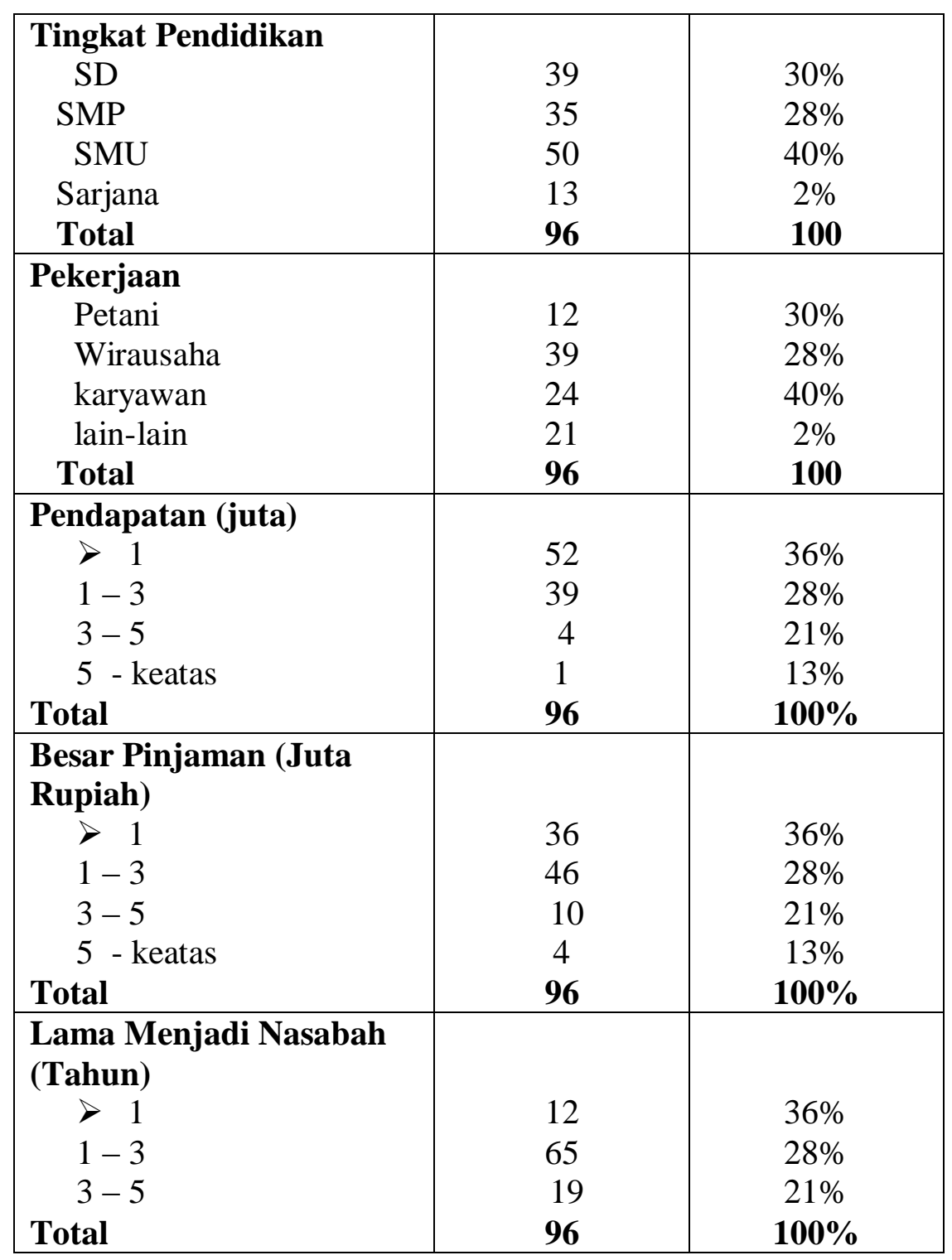




\section{HASIL DAN PEMBAHASAN}

Analisis data dilakukan dengan bantuan aplikasi program SPSS18.00. Analsis ini meliputi analisis diskriptif meliputi frekuensi dan prosentase dari sampel. Untuk menguji hipotesis, penelitian ini menggunakan regresi yang menguji pengaruh biaya, angsuran dan pelayanan konsumen terhadap kepuasan konsumen.

Tabel II melaporkan hasil analisis statistik diskriptif meliputi mean, standar diviasi dan korelasi antar variabel. Dari hasil ini dapat kita lihat rata-rata jawaban dari responden menunjukkan bahwa persepsi nasabahpembiayaan terhadap biaya yang mereka bayar atas pinjaman yang mereka dapatkan nilai rata-rata sebesar 3.55 dengan standard deviasi sebesar 0.73 . Sedangkan persepsi nasabah terhadap angsuran yang harus mereka bayarkan cukup baik dengan nilai rata-rata sebesar 3.65. Nilai rata-rata kualitas layanan BMT terhadap nasabah pembiayaan sebesar 3.85, hal ini menunjukkan bahwa nasabah pembiayaan yang ada di BMT di kabupaten Kudus sudah dilayani dengan baik. Sedangkan nilai rata-rata kepuasan nasabah pinjaman secara keseluruhan sebesar 3,74, hal ini menunjukkan bahwa tingkat kepuasan konsumen pinjaman terhadap keseluruhan aspek yang ada di BMT yang dirasakan oleh naabah BMT kabupaten Kudus cukup tinggi, yaitu mendekati angka 4 dari skala 5 poin.

Lebih lanjut, tabel II juga menjelaskan korelasi atau hubungan antar variabel dalam penelitian: biaya, angsuran dan pelayanan konsumen terhadap kepuasan konsumen. Hasil analisis korelasi menunjukkan bahwa kepuasan konsumen dengan biaya adalah positif signifikan ( $\mathrm{r}=0.502$; $\mathrm{p}<0.01)$, hubungan angsuran dengankepuasan nasabah $(\mathrm{r}=0.645 ; \mathrm{p}<$ 0.01) dan begitu juga hubungan kualitas pelayanan dengankepuasan nasabah $(\mathrm{r}=0.683 ; \mathrm{p}<0.01)$. Hasil uji korelasi inimenunjukkan bahwa hubungan antar variabel dalam penelitian menunjukkan hubungan positif dan signifikan. 
Tabel II Mean, Standar Deviasi, Korelasi Antar Variabel

\begin{tabular}{|l|l|r|c|c|c|c|}
\hline No & \multicolumn{1}{|c|}{ Variables } & Mean & SD & $\mathbf{2}$ & $\mathbf{3}$ & $\mathbf{4}$ \\
\hline 1 & Biaya & 3.55 & .73 & $.721^{* *}$ & $.384^{* *}$ & $.502^{* *}$ \\
\hline 2 & Angsuran & 3.65 & .80 & 1.00 & $.560^{* *}$ & $.645^{* *}$ \\
\hline 3 & $\begin{array}{l}\text { Kualitas } \\
\text { Pelayanan }\end{array}$ & 3.85 & .61 & & 1.00 & $.683^{* *}$ \\
\hline 4 & $\begin{array}{l}\text { Kepuasan } \\
\text { Nasabah }\end{array}$ & 3.74 & .73 & & & 1.00 \\
\hline
\end{tabular}

$* \mathrm{p}<.05 ; * * \mathrm{p}<.01$

Hasil uji regresi di tunjukkan pada tabel III berikut ini:

Tabel III. Hasil Analisis Regresi

\begin{tabular}{|c|c|c|c|}
\hline \multirow{2}{*}{ Variables } & \multicolumn{3}{|c|}{$\begin{array}{c}\text { Variabel Dependen } \\
\text { Kepuasan Konsumen }\end{array}$} \\
\cline { 2 - 4 } & $\mathbf{B}$ & $\mathbf{t}$ & $\mathbf{R}^{\mathbf{2}}$ \\
\hline Independen Variabel & & & \multirow{2}{*}{ t } \\
- Biaya Pinjaman & 0.050 & 0.508 & $.597^{* *}$ \\
- Angsuran & $0.233^{*}$ & $2.340^{*}$ & \\
- Kualitas Pelayanan & $0.494^{* *}$ & $4.894^{* *}$ & \\
& & & \\
& & & \\
\hline
\end{tabular}

Note: $* \mathrm{p}<0.05, * * \mathrm{p}<0.01$

Dari hasil tabel diatas dapat kita lihat hasil analisis regresi menunjukkan pengaruh biaya, angsuran, dan kualitas pelayanan terhadap kepuasan konsumen. Hipotesis pertama menguji pengaruh biaya terhadap kepuasan konsumen menunjukkan nilai $\mathrm{t}$ sebesar 0.508 dengan tingkat signifikansi diatas 10 persen, dengan demikian maka Ha ditolak dan Ho diterima. Hal ini menunjukkan bahwa hipotesis pertama tidak terbukti. Hasil ini menunjukkan bahwa biaya atau bagi hasil yang dibayarkan oleh 
nasabah pembiayaan di BMT di kabupaten Kudus tidak berpengaruh terhadap kepuasan nasabah pembiayaan.

Hasil uji t pada tabel diatas menunjukkan bahwa pengaruh angsuran terhadap kepuasan konsumen positif dan signifikan dengan nilai t sebesar 2.34 dengan tingkat signifikansi dibawah 0.05. Hal ini menunjukkan bahwa hipotesis kedua terbukti dan dapat diterima, dengan menolak Ho dan Ha diterima. Dengan nilai koefisien beta yang positif ini menunjukkan bahwa model angsuran yang diberlakukan di BMT memiliki efek yang positif terhadap kepuasan konsumen. Dengan perkataan lain, model angsuran yang harus dibayarkan nasabah pembiayaan BMT di kabupaten Kudus dapat diterima oleh para konsumen pembiayaan, hal ini model angsuran baik harian, mingguan maupun bulanan sesuai dengan yang diharapkan oleh para nasabah pembiayaan.

Hasil tabel di atas juga menunjukkan bahwa kualitas pelayanan berpengaruh terhadap kepuasan konsumen pembiayaan. Nilai t sebesar 4.894 dengan tingkat signifikansi dibawah 0.01 menunjukkan adanya pengaruh positif dan signifikan antara kualitas pelayanan dan kepuasan konsumen. Hal ini menunjukkan bahwa hipotesis ketiga terbukti dan dapat diterima, dengan menolak Ho dan Ha diterima. Dengan nilai koefisien beta yang positif ini menunjukkan bahwa kualitas pelayanan yang diberlakukan di BMT memiliki efek yang positif terhadap kepuasan konsumen. Dengan perkataan lain, pelayanan yang diberikan karyawan BMT kepada nasabah pembiayaan BMT di kabupaten Kudus dapat diterima oleh para konsumen pembiayaan.

Selanjutnya, dari hasil perhitungan diatas dapat diketahui bahwa koefisien determinasi $\left(\mathrm{R}^{2}\right)$ yang diperoleh sebesar 0.597 dengan tingkat signifikansi dibawah 0.01. Hasil ini berarti bahwa variabel biaya, angsuran dan kepuasan dapat menjelaskan variabel kepuasan konsumen sebesar 59.7\%, sedangkan sisanya 40,3\% dijelaskan oleh variabel lain.

Dari hasil analisis deskriptif secara umum variabel pada penelitian ini mendapatkan penilaian dari responden cukup baik. Hal ini dapat ditunjukkan dari tanggapan persetujuan yang tinggi dari responden terhadap setiap variabel yang diteliti. Dari hasil tersebut diperoleh kesimpulan bahwa ada pengaruh positif dari angsuran dan kualitas pelayanan terhadap kepuasan 
konsumen pada nasabah pembiayaan BMT di Kabupaten Kudus, sedangkan variabel biaya tidak berpengaruh terhadap kepuasan nasabah.

Pengujian hipotesis pertama menunjukkan bahwa variabel biaya tidak berpengaruh terhadapkepuasan konsumen. Hasil ini menunjukkan bahwa beban biaya yang harus dibayar oleh nasabah pembiayaan di BMT cukup membebani para nasabah pinjaman sehingga tidak berpengaruh terhadap kepuasan nasabah pinjaman atau pembiayaan. Sedangkan hasil uji korelasi dalam penelitian ini menemukan bahwa biaya pembiayaan berhubungan dengan kepuasan nasabah pembiayaan, hal ini sesuai dengan penelitian ini sejalan dengan penelitian yang dilakukan oleh Ashraf dan Noor, (2010), yang menemukan bahwa adanya keterkaitan antara biaya pinjaman dengan tingkat kepuasan konsumen lembaga keuangan mikro di Bangladesh.Namun demikian, uji t tidak menemukan pengaruh dari biaya pinjaman terhadap kepuasan nasabah pembiayaan di BMT di Kabupaten Kudus. Dari hasil pengamatan lapangan melihat adanya kemungkinan kenapa biaya pinjaman tidak berpengaruh terhadap kepuasan nasabah pembiayaan yaitu nasabah pembiayaan mungkin menganggap biaya yang dibebankan kepadanya lebih tinggi bila dibandingkan dengan bunga yang ada di bank atau lembaga keuangan konvensional, sehingga mereka kurang puas dengan beban biaya yang harus dibayarkan. Hasil pengamatan ini sesuai dengan penelitian yang dilakukan oleh Masyita dan Ahmed (2010) yang membandingkan kredit UMKM yang diberikan lembaga keuangan mikro syariah dan lembaga keuangan mikro konvensional dengan sampel 518 usaha kecil, hasilnya menunjukkan bahwa cost of capital (biaya modal) dari lembaga keuangan mikro syariah lebih tinggi dari lembaga keuangan mikro konvensional. Hasil ini memberi gambaran bahwa persepsi konsumen pembiayaan terhadap biaya pinjaman (cost of loan) dari lembaga keuangan mikro syariah di kabupaten Kudus dianngap cukup tinggi/ mahal di banding dengan lembaga keuangan lain, hal ini bisa menjadi pelajaran bagai lembaga keuangan mikro syariah untuk melakukan efesiensi operasional organisasi sehingga bisa memberi pembiayaan dengan biaya yang lebih murah. 
Hasil pengujian hipotesis kedua yang menguji pengaruh angsuran terhadapkepuasan konsumen pembiayaan terbukti berpengaruh secara positif dan signifikan. Hal ini menunjukkan bahwa model angsuran jemput bola dan fleksibel yang diterapkan oleh lembaga keuangan mikro syariah di kabupaten Kudus disukai oleh peminjam. Model angsuran pembiayaan yang diberlakukan oleh lembaga keuangan mikro syariah di kabupaten Kudus yang diberlakukan BMT dengan model harian, mingguan maupun cukup berpengaruh terhadap kepuasan konsumen. Model angsuran yang cukup fleksibel ini disesuaikan dengan kemampuan dan keinginan konsumen sehingga konsumen pembiayaan merasa puas atas model angsuran ini.Penelitian ini mendapat dukungan dari penelitian sebelumnya yang penelitian ini sejalan dengan penelitian yang dilakukan oleh Ashraf dan Noor (2010) yang menemukan bahwa adanya keterkaitan antara model angsuran terhadap kepuasan konsumen lembaga keuangan mikro di Bangladesh.

Hipotesis ketiga yang menguji kualitas pelayanan sangat berpengaruh terhadap kepuasan nasabah pembiayaan, hasilnya menunjukkan positif dan signifikan. Hasil ini juga didukung hasil uji statistik diskriptif menunjukkan adanya hubungan yang erat antara kualitas layanan dengan kepuasan nasabah pembiayaan BMT. Penelitian ini juga sesuai dengan penelitian penelitian ini sejalan dengan penelitian yang dilakukan oleh Bashir, Machali dan Mwinyi (2012) menemukan adanya pengaruh kualitas pelayanan dengan tingkat kepuasan konsumen pembiayaan lembaga keuangan mikro di Bangladesh. Hasil ini memberi gambaran bahwa kualitas layanan yang diberikan lembaga keuangan mikro syariah di kabupaten Kudus cukup baik. Berbagai komponen dari kualitas pelayanan seperti fasilitas fisik, kualitas sumberdaya manusia, pelayanan yang cepat dan ramah, jaminan keamanan transaksi serta berbagai komponen penting dalam kualitas pelayanan dianggap cukup baik oleh nasabah pembiayaan BMT di Kudus. Hal ini juga dapat dilihat dari hasil statistik diskriptif yang menunjukkan nilai kualitas layanan di BMT dukup baik. Dari hasil penelitian ini menunjukkan bahwa manajer lembaga keuangan mikro syariah perlu memperhatikan kualitas layanan yang diberikan karena akan berdampak pada kepuasan nasabah pembiayaan. 


\section{PENUTUP}

\section{Kesimpulan}

Dari hasil analisis data penelitian ini, ada beberapa kesimpulan yang dapat diambil dari penelitian ini yaitu: pertama, berdasarkan analisis statistik diskriptif, hasil penelitian ini menunjukkan bahwa persepsi nasabah pembiayaan BMT terhadap biaya, angsuran, kualitas layanan cukup tinggi. Hal ini dapat dilihat dari rata-rata dari tiga variabel tersebut mendekati angka 4 dari 5 skala pengukuran. Hasil ini menunjukkan bahwa nasabah pembiayaan BMT di Kudus merasakan bahwa biaya, angsuran dan kualitas pelayanan yang diberikan cukup baik. Lebih lanjut, Berdasarkan hasil analisis data kepuasan konsumen pembiayaan mendapat nilai rata-rata 3,7 , hal ini menunjukkan bahwa nasabah pembiayaan cukup puas dengan yang lembaga keuangan mikro berikan kepada mereka selama ini.

Kedua, berdasarkan analisis secara parsial menunjukkan bahwa angsuran dan kualitas layanan mempunyai pengaruh positif signifikan terhadap kepuasan konsumen pembiayaan. Sedangkan pengaruh biaya pinjaman terhadap kepuasan nasabah pembiayaan tidak signifikan. Hasil ini menunjukkan bahwa nasabah pembiayaan BMT atau koperasi jasa syariah di Kudus merasakan bahwa biaya pinjaman yang dibebankan kepada nasabah cukup berat sehingga cukup membebani kemajuan usaha mereka. Hal ini mungkin disebabkan karena nasabah pembiayaan membandingkan biaya pinjaman yang ada di lembaga keuangan mikro syariah lebih tinggi disbanding dengan biaya pinjaman di lembaga perbankan, sehingga merasa biaya pinjaman lembaga keuangan mikro syariah lebih mahal sehingga membuat nasabah pembiayaan tidak puas dengan besarnya biaya pinjaman tersebut.

Ketiga, berdasarkan pengujian secara simultan, ternyata penelitian ini membuktikan bahwa secara bersama-sama variabel independen (biaya, angsuran, kualitas layanan) mempunyai pengaruh positif signifikan terhadap variabel dependen yaitu kepuasan konsumen pembiayaan. Hasil uji simultan ini menunjukkan bahwa biaya pinjaman yang dibebankan, model angsuran yang cukup fleksibel dan kualitas 
layanan yang baik diberikan lembaga keuangan mikro syariah cukup berpengaruh terhadap kepuasan nasabah pembiayaan cukup mewakili sebesar 59,7 persen, sedangkan sisanya dipengaruhi oleh variabel lain.

\section{Implikasi}

Berdasarkan hasil analisis, penelitian ini memiliki dua implikasi yaitu implikasi teoritis maupun implikasi praktis. Adapun implikasi teoritis dari penelitian ini adalah bahwa angsuran dan kualitas layanan memiliki pengaruh positif terhadap kepuasan konsumen pembiayaan, sedangkan biaya pinjaman tidak berpengaruh secara signifikan terhadap kepuasan nasabah pembiayaan. Hasil penelitian ini akan berimplikasi secara teoritis dapat dijadikan dasar bagi penelitian selanjutnya.

Sedangkan implikasi praktis bagi manajer dan para praktisi di BMT antara lain: pertama, para menajer perlu memperhatikan besarnya biaya pinjaman yang dibebankan nasabah pembiayaan, hasil penelitian ini dapat dijadikan pelajaran bagi pengelola lembaga keuangan mikro syariah umtuk melakukan efesiensi biaya operasional sehingga dapat menurunkan biaya pinjaman yang dianggap mahal oleh para nasabah pembiayaan. Penentuan besaran biaya yang dibebankan kepada nasabah hendaknya ditentukan secara fair dan tidak membebani para pengusaha kecil dalam mengembalikan pinjaman yang diperoleh.

Kedua, manajer BMT juga perlu memperhatikan model angsuran yang diterapkan di institudinya. Penilaian nasabah pembiayaan lembaga keuangan mikro syariah di Kudus cukup baik terhadap model angsuran yang selama ini diberlakukan.Model angsuran yang sangat fleksibel sesuai dengan kemampuan nasabah pembiayaaan yang mayoritas pedagang pasar.Model angsuran jemput bola dan model pembayaran yang sangat fleksibel baik harian, mingguan, bulanan maupun musiman sangat berpengaruh terhadap kepuasan nasabah pembiayaan sehingga para manajer BMT perlu mempertahankan model angsuran yang selama ini dilakukan. Ketiga, manajer BMT juga perlu memperhatikan kualitas layanan yang diberikan. Hasil penelitian ini menunjukkan bahwa kualitas layanan sangat berpengaruh terhadap kepuasan konsumen pembiayaan. Pengelola BMT 
harus memperhatikan kualitas layanan seperti fasilitas fisik, kualitas sumberdaya manusia, pelayanan yang cepat dan ramah, jaminan keamanan transaksi sangat berpengaruh terhadap kepuasan nasabah pembiayaan. Layanan yang berkualitas akan berpengaruh terhadap kepuasan nasabah pembiayaan yang akan menyampaikan kepada calon-calon nasabah lain yang merupakan sumber kehidupan lembaga keuangan syariah di Kudus.

\section{Keterbatasan dan Saran}

Dari hasil-hasil yang diperoleh pada penelitian ini, ada beberapa kelemahan yang perlu dibenahi untuk penelitian yang akan datang supaya mendapatkan hasil yang lebih baik. Adapun keterbatan dan saran adalah sebagai berikut: pertama, kuesioner hanya didistribusikan di BMT di Kabupaten Kudus saja, sehingga cakupan penelitian ini cukup sempit. Hal ini menyebabkan tingkat generalisasi hasil penelitian ini kurang. Penelitian lanjutan hendaknya mengambil sampel di tingkat yang lebih luas seperti di wilayah Jawa Tengah atau Jawa sehingga hasilnya bisa di generalisasi. Kedua, variabel yang dilibatkan dalam penelitian sedikit, hanya biaya, angsuran dan kualitas layanan. Penelitian lanjutan hendaknya memasukkan variabel keberagamaan (kesesuaian dengan syariah, keabsahan akad), prosedur pengajuan, besar dan kecil pembiayaan dan lainnya sehingga cakupan variabel lebih luas. Kelemahan yang terakhir, penelitian ini hanya menggunakan data kroseksional yaitu diambil pada satu saat saja, penelitian lanjutan lebih baik dilakukan secara longitudinal yaitu pengamatan jangka panjang sehingga akan menghasilkan kajian yang lebih komprehensif. 


\section{DAFTAR PUSTAKA}

Ashraf, M. A. dan Noor, M. S.I. (2010). Microfinance Customer (Borrower) Experience Towards The Effectiveness of MFIs In Bangladesh: An Exploratory Analysis. $A B A C$ Journal, 30(2), 12-25.

Awojobi, O dan Murad Bein, M.A. (2011). Microfinancing for Poverty Reduction and Economic Development; a Case for Nigeria.International Research Journal of Finance and Economics, 1(72), 159-168.

Aziz, M.A. (2004). The Prospect of BMT in Indonesia, Centre for Small and Medium Enterprises Incubation (PINBUK), Jakarta.

Bashir, M. S., Machali, M. M., dan Mwinyi, A. M., (2012). The Effect of Service Quality and Government Role on Customer Satisfaction: Empirical Evidence of Microfinance in Kenya. International Journal of Business and Social Science, 3(14), 312-319.

BI (2016). Pemetaan dan Strategi Peningkatan Daya Saing UMKM dalam Menghadapi Masyarakat Ekonomi ASEAN (2015) dan Pasca MEA 2025, sumber: http://www.bi.go.id/id/umkm/penelitian/nasional/kajian/ Documents/Pemetaan\%20dan\%20Strategi\%20Peningkat an\%20Daya\%20Saing\%20UMKM\%20dalam\%20Mengh adapi\%20Masyarakat\%20Ekonomi\%20ASEAN\%20(201 5)\%20dan\%20Pasca\%20MEA\%202025.pdf

Chowdhury, A. M. R., dan Bhuiya, A. (2004). The wider impacts of BRAC poverty alleviation programme in Bangladesh. Journal of International Development 16(3), 369-386.

Coleman, B.E. (1999). The Impact of group lending in Northeast Thailand.Journal of Development Economics, 60, 105141.

Durrani, M.K.K., Usman, A., Muhammad Imran Malik, M.I., dan Ahmad, S. (2011). Role of Micro Finance in Reducing Poverty: A Look at Social and Economic Factors. International Journal of Business and Social Science, 2 (21), 138-144. 
Gebru, B. dan Paul, I. (2011). Role of Microfinance in Alleviating Urban Poverty In Ethiopia. Journal of Sustainable Development In Africa, 13(6), 165-180.

Gurses, D. (2009). Micro-finance and Poverty Reduction in Turkey.Perspectives On Global Development and Technology, 8(1), 90-110.

Hasan, N.M., Mohd Nor, A.B dan Mohd Rom, A.A. (2012). Embracing Microfinance: Proposed collaboration between zakat Institution and Microfinance Institutions.

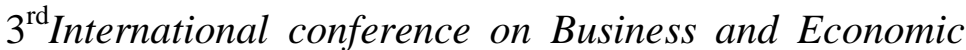
Research Proceeding. Bandung, Indonesia.

Hassan, M.K. (2010). An Integrated Poverty Alleviation Model Combining Zakat, Awqaf and Micro-finance. Seventh International Conference (The Tawhidi Epistemology), 1-21.

Kanyurhi, E., B. (2013). Evaluation of customer satisfaction with services of a micro-finance institution: Empirical evidence from Women Association for Social and Economic Gain. African Journal of Marketing Management, 5(2), 26-37.

Kessy, S.A dan Urio, F. M. (2006). Contribution of Microfinance Institutions to poverty Reduction in Tanzania.sumber:http://www.repoa.or.tz/documents_stor age/Publications/Reports/06.3 Kessy and Urio.pdf

Khan, S., Naeem, A., dan Kasi, M., S. (2012). Micro Finance and Small Enterprises Development: Client perspective Study of Baluchistan, Pakistan. International Journal of Art and Commerce, 1(5), 279-292.

Khandker, S. (1998). Fighting poverty with microcredit: experience from Bangladesh. New York: Oxford University Press for the World Bank.

Kotler, P. (2009). Manajemen Pemasaran. Jakarta : Erlangga

Masyita, D., dan Ahmed, H. (2011). Why is Growth of Islamic Microfinance Lower than Conventional? : A Comparative Study of the Preferences and Perceptions of the Clients of Islamic and Conventional Microfinance Institutions' in Indonesia. Paper dipresentasikan di International Conference on Islamic Economics and Finance ke 8, Doha, Qatar. 19-21 Desember 2011. 
Mirghani, M., Mohammed, M., Bhuiyan, A.A., dan Siwar (2011). Islamic Microcredit and Poverty Allevation in the Muslim World: Prospects and Challages. Australian Journal of Basic and Applied Sciences, 5(9), 620-626.

Obaidullah M. dan Khan, T. (2008). Islamic Microfinance Development - Challenges and Initiatives. Policy dialogue Paper No. 2, IRTI, Islamic Development Bank, Jeddah.

Okpara, G.C. (2010). Microfinance Banks and Poverty Alleviation In Nigeria, Journal of Sustainable Development In Africa, 12(6), 177-191.

Rahman, M.M. (2010). Islamic micro-finance programme and its impacton rural poverty alleviation. International Journal of Banking and Finance, 7 (1), 119-138.

Rokhman, W. (2013). The Effect of Islamic Microfinance on Poverty Alleviation: Study In Indonesia. Economic Review: Journal of Economics and Business, 11(2), 2130.

Rokhman, W. dan Rivai, H.A. (2014). Evaluation of Customer Satisfaction on Islamic Microfinance: Empirical Evidence from Central Java, Indonesia, South Asian Journal of Management Sciences, 8(2), 60 - 69.

Sakai dan Marijan, (2008). Mendayagunakan pembiayaan mikro Islami. Publised by Crawford School of Economics and Government, Australian National University.

Sakti, A. (2013). Pemetaan Kondisi dan Potensi BMT: Kemitraan Dalam Rangka memperluas Pasar dan Jangkauan Pelayanan Bank Syariah kepada Usaha Mikro. Jurnal al-Muzara'ah, 1(1), 1-18.

Shirazi, N.S. dan Khan, A.U. (2009), Role of Pakistan Poverty Alleviation Fund's Micro Credit In Poverty Alleviation :A Case of Pakistan.Pakistan Economic and Social Review, 7(2), 215-228.

Siebel, H. D. dan Agung, W. D. (2005). Islamic Microfinance in Indonesia.Published by University of Cologne Development Center.

Soesastro, H dan Basri, M. K. (2005). The Political Economy of Trade Policy in Indonesia, Economics Working Paper Series, sumber: http://www.csis.or.id/papers/wpe092. 
Suryahadi, A., Hadiwidjaja, G., dan Sumarto, S. (2012). Economic Growth and Poverty Reduction in Indonesia Before and After the Asian Financial Crisis.The SMERU Research Institute, Jakarta.

Usman, S. Suharyo, W.I., Sulaksono, B. , Mawardi, M.S., , Toyamah, N., dan Akhmadi (2004). Lessons Learned from Microfinance Services In East Nusa Tenggara. SMERU Research Institute Jakarta.

Utami, E.D. dan Setiawan, A.I. (2006). The analysis of BMT's financial performance and internal management: a survey of BMTs in the Banyumas Regency. Journal of Accounting and Finance, 7( 5), 97-114.

Wardiwiyono, S (2012). Internal control system for Islamic micro financing:An exploratory study of Baitul Maal wat Tamwil in the City of Yogyakarta Indonesia. International Journal of Islamic and Middle Eastern Finance and Management, 5(4), 340-352.

Widiyanto, M. C. (2007). Effectiveness of Islamic Microcredit Finance in Indonesia. $\mathrm{PhD}$ dissertation submitted to University Putra Malaysia (UPM), Malaysia.

Widiyanto, M.C. dan Ismail, A.G. (2007). Sustainability of BMT financing for developing microenterprises", Working Paper in Islamic Economics and Finance No. WIEF0601, Sumber: http://pkukmweb.ukm.my/,ekonis/BI/working\%20paper. $\underline{\mathrm{html}}$

Yumna, A.dan Clarke, M. (2012). Integrating zakat and Islamic charities with microfinance initiative in the purpose of poverty alleviation in Indonesia. 8th International Conference on Islamic Economics and Finance, Qatar.

Yusuf, S.A., Amao J.O. dan Olawale, O.T. (2014). Effect of microcredit on small scale enterprises in Osun State, Nigeria. American International journal of Contemporary research, 4(6), 190-200. 